\title{
Ureolytic MICP-Based Self-Healing Mortar under Artificial Seawater Incubation
}

\author{
Xichen Sun ${ }^{1,2}$, Jie Chen ${ }^{2}$, Siyi Lu ${ }^{3}$, Miaomiao Liu ${ }^{2}$, Siyu Chen ${ }^{2}$, Yifei Nan ${ }^{3}$, Yang Wang ${ }^{2, *}$ and Jun Feng ${ }^{1, *}$ \\ 1 National Key Laboratory of Transient Physics, Nanjing University of Science \& Technology, \\ Nanjing 210094, China; sunxichen0046@163.com \\ 2 School of Environmental and Biological Engineering, Nanjing University of Science \& Technology, \\ Nanjing 210094, China; chenjie15251835119@163.com (J.C.); liumiaomiao010718@163.com (M.L.); \\ csy819587671@163.com (S.C.) \\ 3 School of Science, Nanjing University of Science \& Technology, Nanjing 210094, China; \\ lusiyi112023@163.com (S.L.); fyi2333@163.com (Y.N.) \\ * Correspondence: wangyang@njust.edu.cn (Y.W.); jun.feng@njust.edu.cn (J.F.)
}

Citation: Sun, X.; Chen, J.; Lu, S.; Liu, M.; Chen, S.; Nan, Y.; Wang, Y.; Feng, J. Ureolytic MICP-Based Self-Healing Mortar under Artificial Seawater Incubation. Sustainability 2021, 13, 4834. https://doi.org/10.3390/ su13094834

Academic Editor: Riccardo Maddalena

Received: 31 March 2021

Accepted: 23 April 2021

Published: 25 April 2021

Publisher's Note: MDPI stays neutral with regard to jurisdictional claims in published maps and institutional affiliations.

Copyright: (c) 2021 by the authors. Licensee MDPI, Basel, Switzerland. This article is an open access article distributed under the terms and conditions of the Creative Commons Attribution (CC BY) license (https:/ / creativecommons.org/licenses/by/ $4.0 /)$.

\begin{abstract}
Ureolytic microbial-induced calcium carbonate precipitation (MICP) is a promising green technique for addressing sustainable building concerns by promoting self-healing mortar development. This paper deals with bacteria-based self-healing mortar under artificial seawater incubation for the sake of fast crack sealing with sufficient calcium resource supply. The ureolytic MICP mechanism was explored by morphology characterization and compositional analysis. With polyvinyl alcohol fiber reinforcement, self-healing mortar beams were produced and bent to generate $0.4 \mathrm{~mm}$ width cracks at the bottom. The crack-sealing capacity was evaluated at an age of 7 days, 14 days, and 28 days, suggesting a 1-week and 2-week healing time for 7-day- and 14-day-old samples. However, the 28-day-old ones failed to heal the cracks completely. The precipitation crystals filling the crack gap were identified as mainly vaterite with cell imprints. Moreover, fiber surface was found to be adhered by bacterial precipitates indicating fiber-matrix interfacial bond repair.
\end{abstract}

Keywords: microbial-induced calcium carbonate precipitation; Bacillus; biomineralization; selfhealing mortar; vaterite morphology

\section{Introduction}

Concrete is one of the most widely used human-made materials for construction and infrastructure of, e.g., highways, dams, harbors, bridges, tunnels, etc. [1,2]. However, concrete structures are very sensitive to crack formation due to their inherent brittleness with properties that are strong in compression but weak in tension [3-5]. The formation of cracks in concrete is dependent on concrete's microstructural properties, e.g., defect and heterogeneity [6,7]. Cracking-induced physical and chemical deteriorations are the main culprits endangering the integrity, durability, and safety of concrete structures [8-10]. The conventional crack repair method can be used after detection, but it is very difficult to deal with cracks which are either too fine or too deeply embedded to be accessible in infrastructures that are in continuous use. Hence, further studies on the search for a smart or automatic method to heal the cracking of concrete structures are of great importance [11,12]. It is widely acknowledged that bacterial-based self-healing is a promising solution to reduce the tremendous maintenance and repair costs of concrete infrastructures [13-15].

Designed to overcome the inevitable problem of crack formation in concrete structures, self-healing concrete is an established technology which incorporates a healing agent and which consists of carbonate-precipitating bacteria and a calcium source during the process of mixing $[16,17]$. Once cracking occurs, the embedded microorganisms near the crack zone will be activated and start to precipitate $\mathrm{CaCO}_{3}$, filling the cracking gaps. In the 1990s, Gollapudi et al. [18] first introduced bacteria to cementitious materials to induce calcium 
carbonate precipitation to remediate cracks. Different bacteria induce calcium carbonate precipitation through different metabolic processes: urease decomposing urea [13,19-21] and carbonic anhydrase aiding $\mathrm{CO}_{2}$ capture [14,22-24]. Both pathways help to induce a reaction between carbonate and $\mathrm{Ca}^{2+}$ to form $\mathrm{CaCO}_{3}$ in an alkaline environment. Owing to the remarkably high productivity of calcium carbonate precipitation, studies on ureolytic MICP with applications in self-healing concrete development are being extensively conducted via the technical route of urea hydrolysis [25,26].

For typical ureolytic MICP, urea is hydrolyzed through microbial-induced urease to produce ammonium and carbonate ions, which leads to an increased $\mathrm{pH}$ in the neighboring environment. Such local $\mathrm{pH}$ increase triggers the precipitation of $\mathrm{CaCO}_{3}$ in the presence of calcium ions $[27,28]$. The biological-chemical mechanism of the ureolytic MICP process is significantly dependent on the concentration of calcium ion, carbonate, and $\mathrm{pH}[29,30]$. Therefore, a conventional self-healing incubation environment (i.e., water) is not the most favorable for spore germination, as well as efficient MICP. The incubation condition for cracked concrete specimens is a vital factor for fast crack sealing of microbial self-healing concrete [31].

Previous researchers have mainly focused on the incubation period of self-healing concrete, either with humid air or a water environment, i.e., fully immersed in water or subjected to wet-dry cycles [32-35]. According to [13], specimens were alternately submerged in tap water for $1 \mathrm{~h}$ and then exposed to humid air at room temperature for $11 \mathrm{~h}$. Despite the fact that specimens were in a water environment for only $2 \mathrm{~h}$ per day, a complete crack sealing was achieved after four weeks of incubation. Kalhori and Bagherpour [36] compared different incubation environments' effects on concrete compressive strength, whereby water, reactive solution and suspension of bacteria, and urea and calcium chloride were utilized for healing conditions. It was revealed that the compressive strength of specimens immersed in bacterial suspension was approximately $30 \%$ higher than that of those immersed in water or reactive solution. More recently, Hamza et al. [33] dealt with the soil incubation effect on mortar self-healing performance considering typical underground concrete structures. The experimental results implied that microbial self-healing concrete generally proceeds in a similar fashion within saturated natural soil to that of concrete incubated in humid air and water [33]. Although research to date has focused on water environment incubation, few reports on the effect of seawater on self-healing can be found. Palin et al. [3] chose artificial seawater for incubation to simulate a marine environment of coastal and offshore structures. In total, $93 \%$ permeability reduction was realized for $0.6 \mathrm{~mm}$ width cracks in cementitious composites.

In reality, marine and seashore infrastructures are more likely to deteriorate and corrode since they are exposed to seawater chemical attack. The development of self-healing concrete is urgently needed for marine environments. Additionally, $\mathrm{Ca}^{2+}$ in seawater might provide an additional calcium resource, promoting $\mathrm{CaCO}_{3}$ precipitation [37]. Whether the crack sealing of self-healing concrete in an artificial sea water environment can be accelerated and how concrete of different ages behaves need to be investigated. In this research, an ureolytic, alkali-tolerant spore-forming Bacillus strain was used for bio-self-healing mortar to evaluate its crack-sealing performance under artificial seawater incubation. Beam mortar specimens were subjected to bending to generate ideal cracks at the bottom. Flexural strength evaluation and crack-filling material identification were also conducted to characterize crack-sealing performance with artificial seawater incubation.

\section{Ureolytic MICP}

The detailed biochemical reaction process at a single-cell level is explicitly plotted in Figure 1. The Bacillus microorganism generates urease, acting as the enzyme helps to hydrolyze urea to ammonia and carbon dioxide. The production of ammonia causes the $\mathrm{pH}$ of the bacteria-surrounding environment to increase, which promotes $\mathrm{CaCO}_{3}$ in calcium-rich conditions. Precipitation accumulation on the bacterial surface is due to the nucleation effect, since the negatively charged cell surface might attract $\mathrm{Ca}^{2+}$ ions. 


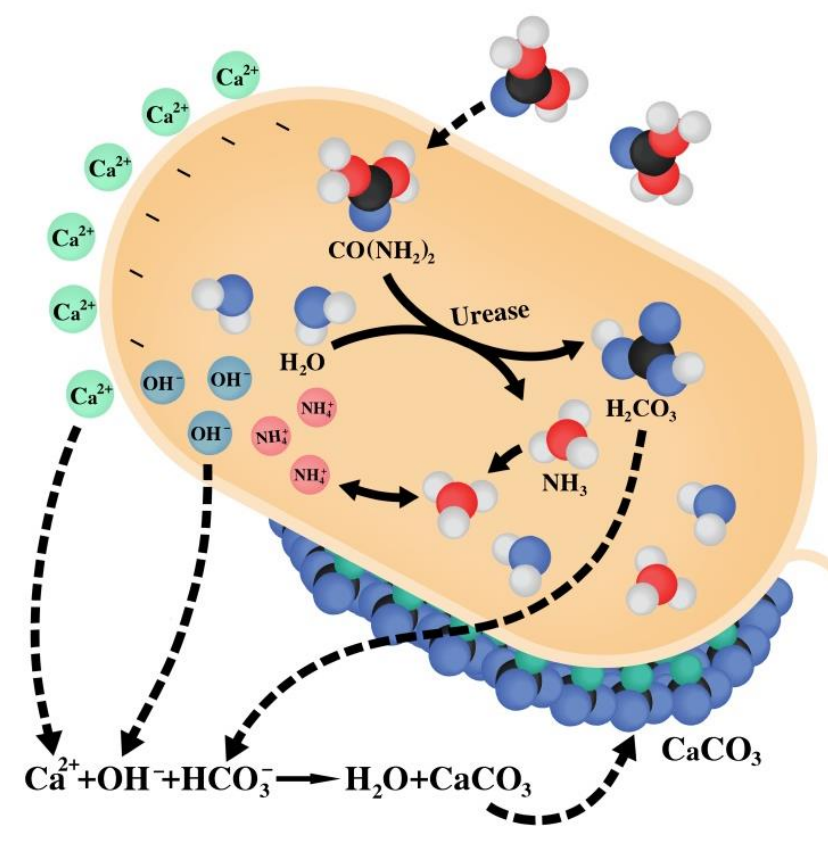

Figure 1. MICP mechanism diagram at a single-cell level.

\subsection{Characterization of Bacillus Strain}

The Bacillus growth profile is represented in terms of optical density of the microbial culture medium at $37^{\circ} \mathrm{C}$, as shown in Figure 2a. The Bacillus microorganism grows rapidly in the first $16 \mathrm{~h}$ and then enters the stationary phase, whereas bacterial density is about $6 \times 10^{7}$ cells $/ \mathrm{mL}$, corresponding to a $8.6 \mathrm{OD}_{600}$ value. Meanwhile, the bacterial solution $\mathrm{pH}$ also increases with bacterial growth and finally stabilizes at about 10 . This phenomenon stems from the fact that bacterial cells decompose urea and produce a large amount of hydroxide, which thus increases solution $\mathrm{pH}$ for the sake of calcium carbonate precipitation.

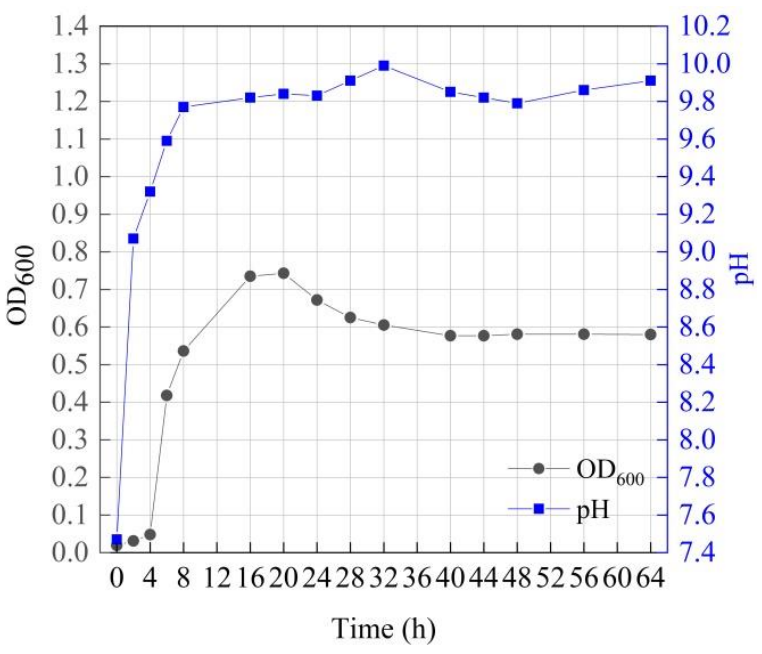

(a)

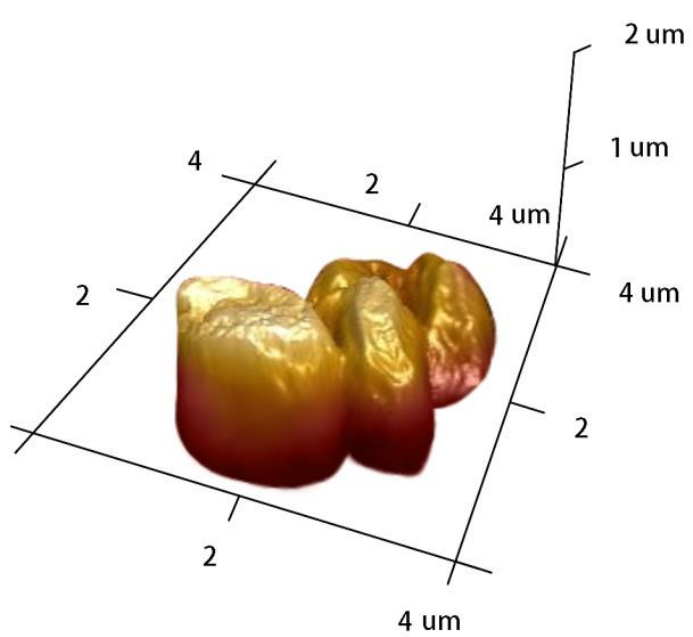

(b)

Figure 2. Bacillus strain characterization: (a) bacterial growth profile; (b) bacterial cell image by AFM.

The microscopic morphology of the Bacillus used in this study was observed via atomic force microscopy (AFM). With Bruker Veeco Multimode 8 AFM (Digital InstrumentsGermany), the Bacillus sample, prepared by scratching bacterial strain on mica sheet to a smooth surface, was tested using a microfabricated silicon tip/cantilever. Microscopic cell characterization with a 3-dimensional sketch is depicted in Figure 2b. The rod-shaped bacteria were about $1.4 \mu \mathrm{m}$ in length and $0.8 \mu \mathrm{m}$ in diameter. 


\subsection{Biomineralization}

The MICP capacity and property determine the crack-sealing potential of self-healing mortar. In a broad view, the ureolytic MICP mechanism studied herein is a sort of biomineralization characterized with $\mathrm{CaCO}_{3}$ production. Providing a sufficient $\mathrm{Ca}^{2+}$ source, the Bacillus strain was cultured at $37^{\circ} \mathrm{C}$ in the incubator and vibrated at $220 \mathrm{rpm}$ for $24 \mathrm{~h}$. After centrifugation, the mineral precipitation crystals were separated and collected from the medium, which were further analyzed with a scanning electron microscope (SEM) and X-ray diffraction (XRD).

In Figure 3, the surface morphology of all particles is roughly round. Sequent energy dispersive spectrometer (EDS) analysis suggests that precipitation samples mainly consist of $\mathrm{C}, \mathrm{O}$, and $\mathrm{Ca}$ according to Figure 4, where $\mathrm{Au}$ is introduced via coating treatment. The XRD results of collected precipitations are depicted in Figure 5 whereby vaterite (denoted by a dot) has very sharp diffraction peaks, and some calcite (labeled with diamond) is also detected. The underlying reason for the hybrid morphology phenomenon might be bacterial metabolic activity (producing calcite) as well as urease catalyzing vaterite. This hybrid morphology needs to be further explored and analyzed in the future.

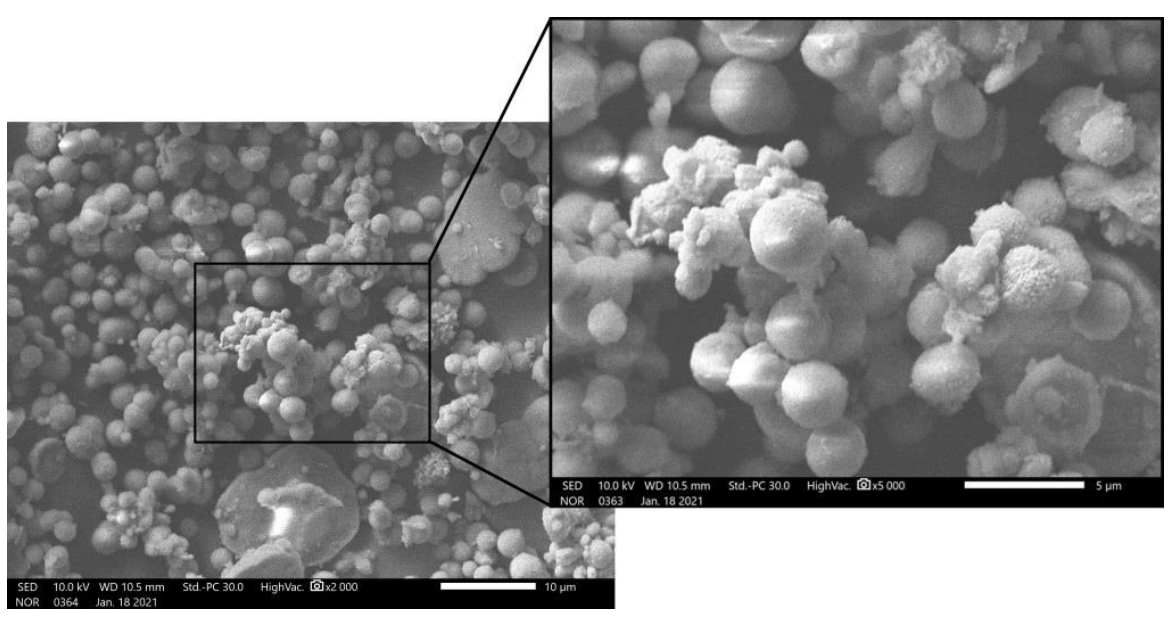

Figure 3. SEM image of biomineralization.

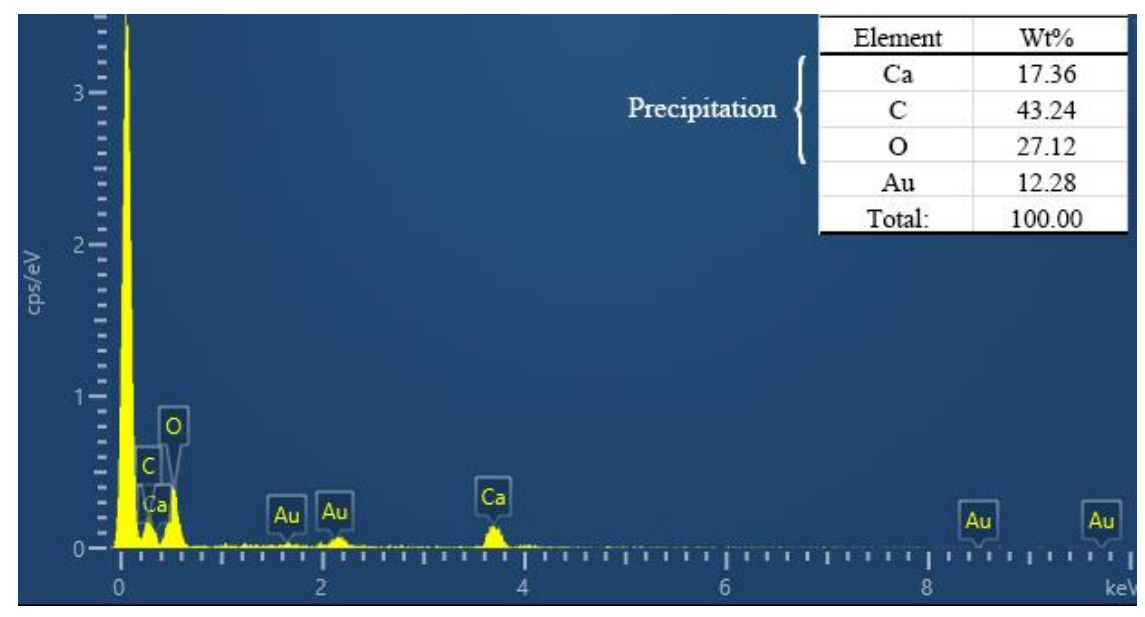

Figure 4. EDS test of MICP crystals. 


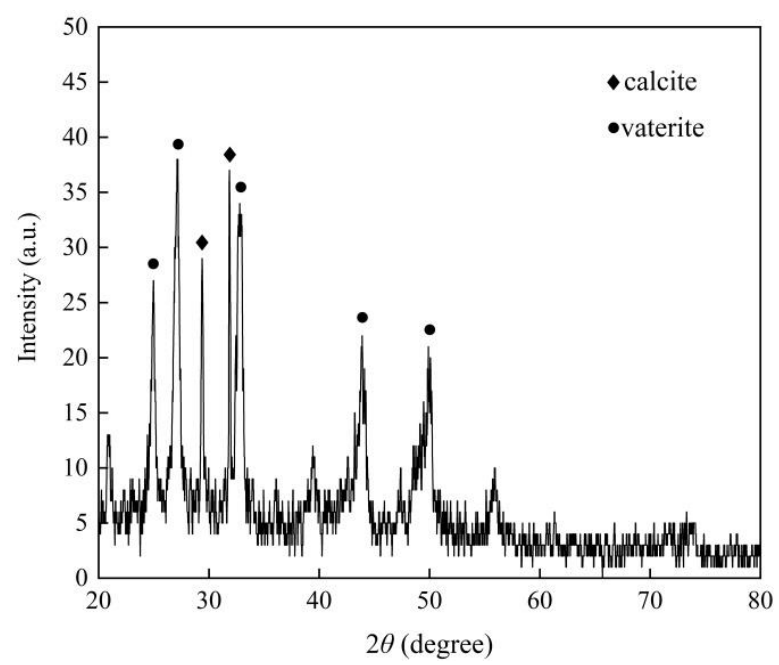

Figure 5. XRD analysis of biomineralization precipitation.

\section{Self-Healing Mortar Production}

Since plain mortar without fiber reinforcement is too brittle to have fracture failure, fiber addition might help to improve its toughness arresting cracking propagation. In order to obtain an ideal typical crack under bending for better crack-healing character assessment, fiber-reinforced mortar was prepared in this study [38]. Exhibiting good compatibility with cementitious matrix, polyvinyl alcohol (PVA) fibers have been widely incorporated to mortar production due to the favorable toughness of mortar reinforced with them $[39,40]$.

With a size of $40 \mathrm{~mm} \times 40 \mathrm{~mm} \times 160 \mathrm{~mm}$, self-healing mortar beam specimens were produced by mixing cement, fly ash, water, quartz sand (particle size ranging from 0.25 to $0.5 \mathrm{~mm}$ ), PVA fiber, and microbial self-healing agent. The normalized mixture proportion is given in Table 1, whereas Portland cement (P.I 42.5) works as cementitious material, and coal fly ash type $C$ is introduced as a mineral active fine admixture. The water-binder and sand-binder ratios are 0.25 and 0.45 , respectively. With a dimension of $12 \mathrm{~mm}$ in length and $26 \mu \mathrm{m}$ in diameter, the incorporated PVA fiber has $1000 \mathrm{MPa}$ tensile strength and $8 \mathrm{GPa}$ Young's modulus. Polycarboxylic acid superplasticizer, a high-performance water-reducing agent, was also introduced to improve the fiber-reinforced mortar fluidity [40]. In order to produce self-healing mortar with a certain living space (ecological niche) for bacteria, a new air-entraining agent, with triterpenoid saponins as its main chemical composition, was incorporated into mortar. Proper air-entraining agent addition can produce plenty of microbubbles with diameters ranging from 10 to $600 \mu \mathrm{m}$, providing suitable space habitats (ecological niches) for microorganisms [21,41].

Table 1. Normalized mixture proportion of self-healing mortar.

\begin{tabular}{ccccccc}
\hline Cement & Fly Ash & Water & Sand & Superplasticizer & Air-Entraining Agent & PVA Fiber \\
\hline 0.9 & 0.1 & 0.3 & 0.36 & $0.4 \%$ & $0.01 \%$ & $1 \%{ }^{1}$ \\
\hline
\end{tabular}

To guarantee sufficient healing agent near the crack, dilution water with $10 \%$ volume well-cultivated Bacillus strain culture was used for self-healing mortar preparation. The specific casting procedures are as follows: (1) Mix the dry binder materials, i.e., cement and fly ash, with fine aggregates in the stirring pot to achieve the binder-sand mixture. (2) Dissolve the water-reducing agent, air-entraining agent, and healing agent into water, and slowly pour the liquid into the binder-sand mixture. (3) Add PVA fibers to the fresh cementitious mortar with even distribution. It took about $8 \mathrm{~min}$ to obtain self-healing mortar with favorable fluidity, which was cast into triplet beam modules. After adequate vibration, the samples underwent a curing regimen and preserved in a standard curing 
room with a constant $20{ }^{\circ} \mathrm{C}$ temperature and $\sim 95 \%$ relative humidity. A total of $24 \mathrm{~h}$ later, beam samples were demolded. For the sake of comparison, 3 triplet modules were prepared with every 3 beam samples cured for 7 days, 14 days, and 28 days, respectively.

\section{Crack-Sealing Evaluation}

To form one localized cracking, a 3-point-bending test was conducted with a 220 kip Instron servo-hydraulic testing system in stroke control mode. As illustrated in Figure 6, the foregoing beam specimen was subjected to downward force with both ends supported, whereby the span is $140 \mathrm{~mm}$. An extensometer was attached to the beam bottom to measure the instant messages of the crack mouth opening displacement (CMOD). To guarantee the quasi-static loading condition, a constant loading rate of $0.5 \mathrm{~mm} / \mathrm{min}$ was applied to the middle of the beam top surface. For all bending tests, the vertical loading cell was stopped once CMOD reached $0.5 \mathrm{~mm}$.

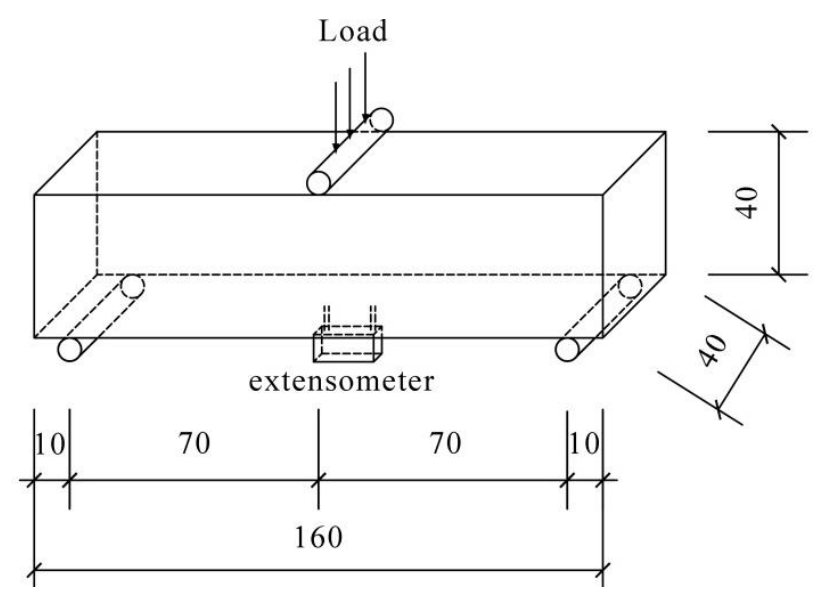

Figure 6. Diagram of 3-point-bending test setup.

\subsection{Incubation with Artificial Seawater}

After the 3-point-bending test, beam specimens were fractured with a localized cracking where $0.4 \mathrm{~mm}$ width cracks occurred at the bottom. As suggested in [3], artificial seawater compositions, i.e., $1.5 \mathrm{~g} / \mathrm{L} \mathrm{CaCl}_{2}, 10.6 \mathrm{~g} / \mathrm{L} \mathrm{MgCl}_{2}, 9.0 \mathrm{~g} / \mathrm{L} \mathrm{NaSO}_{4}$, and $24.1 \mathrm{~g} / \mathrm{L}$ $\mathrm{NaCl}$, were prepared to simulate major constituents of natural seawater condition. The artificial seawater incubation environment was implemented by putting cracked samples to wet-dry cycles. Thus, adequate oxygen and carbon dioxide from atmosphere were available to the microorganism spores to germinate and reproduce. Continuous supply of calcium resource was provided by external artificial seawater. After 4 weeks of incubation, the 7-day-, 14-day-, and 28-day-old self-healing mortar samples were all found to seal to some extent. It was interesting to find that 7-day-old surface cracking was cured after 1 week of incubation, while the 14-day-old ones required 2 weeks to be fixed. Since traditional incubation with tap water takes about 4 weeks to seal cracks [21], putting cracked samples in artificial seawater might help them to seal faster due to sufficient calcium supply. Unfortunately, the 28-day-old counterpart failed to achieve complete sealing as indicated in Figure 7. For the 7-day-old sample, the bacterial cells are more active due to less time in harsh living environment inside concrete. However, microorganisms in the 28-day-old sample were killed or spored, leading to a poor sealing performance. Hence, it might be argued that the artificial seawater environment might accelerate the healing process. Nevertheless, cracks in relatively old samples cannot be completely sealed. 


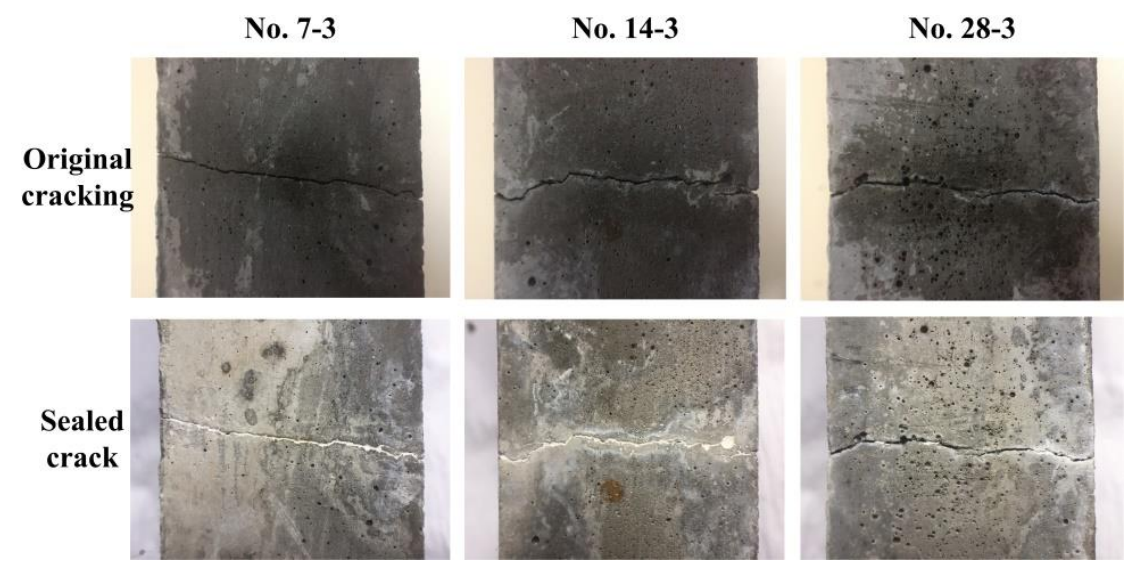

Figure 7. Self-healing of cracked samples with different age.

\subsection{Flexural Strength Evaluation}

After 28 days of incubation, the healing capacity of beam specimens was evaluated via a second-time 3-point-bending test to get the regained flexural strength attribute to crack sealing. The obtained second-time bending flexural strength, defined as healing strength in Table 2, is compared against residual flexural strength, which is defined as stress state of the end of first time bending. The 7-day-, 14-day-, and 28-day-old flexural strength is measured as $7.45 \mathrm{MPa}$, 7.85 MPa, and 9.02 $\mathrm{MPa}$, respectively. In average, 14-day-old specimens exhibited $0.74 \mathrm{MPa}$ regained strength, while 7-day-old ones only recovered $0.43 \mathrm{MPa}$ strength. It is clear that a huge scatter exists for the regained strength, ranging from $0.12 \mathrm{MPa}$ to $0.66 \mathrm{MPa}$ for 7-day-old cracked beams. However, the 14-day-old specimens have a broader regained strength variation between $0.21 \mathrm{MPa}$ and $1.67 \mathrm{MPa}$. The standard deviation of regained strength for 7-day-, 14-day-, and 28-day-old samples is $0.28,0.81$, and $0.08 \mathrm{MPa}$. In general, the flexural strength of 14-day-old samples is better recovered than that of the 7-day-old ones, despite a slower crack-sealing rate. Corresponding to crack-sealing results in Figure 7, the 28-day-old specimens show a negligible strength regaining since they failed to achieve complete remediation. Noting that batch No. 28-3 might suffer further damage during transportation, the regained strength is negative.

Table 2. Repeated 3-point-bending test results of mortar beams (unit: MPa).

\begin{tabular}{ccccccc}
\hline Batch No. & $\begin{array}{c}\text { Flexural } \\
\text { Strength }\end{array}$ & $\begin{array}{c}\text { Residual } \\
\text { Strength }\end{array}$ & $\begin{array}{c}\text { Healing } \\
\text { Strength }\end{array}$ & $\begin{array}{c}\text { Regained } \\
\text { Strength }\end{array}$ & $\begin{array}{c}\text { Standard } \\
\text { Deviation }\end{array}$ \\
\hline $7-1$ & 7.71 & 1.38 & 2.04 & 0.66 & 0.43 & 0.28 \\
$7-2$ & 7.04 & 1.19 & 1.31 & 0.12 & 0.52 & 0.74 \\
$7-3$ & 7.61 & 1.03 & 1.55 & 1.67 & \\
$14-1$ & 7.97 & 1.47 & 3.14 & 0.35 & 0.81 \\
$14-3$ & 7.51 & 1.32 & 1.67 & 0.21 & 0.06 \\
$28-1$ & 8.07 & 1.23 & 1.44 & 0.10 & 0.08 \\
$28-3$ & 8.38 & 1.73 & 1.83 & 0.11 & \\
\hline
\end{tabular}

Figure 8 shows the loading and reloading mechanical responses of beam specimen batch No. 14-1. The loading response is linearly elastic until the peak, followed by a sudden drop due to matrix fracture. As cracking begins and propagates, the PVA fibers crossing the crack gap are activated to bridge the matrix, preventing further cracking. As a result, a relatively ductile behavior is observed in the sequent bending response. The MTS machine kept loading to bend the beam until the crack mouth opening reached $0.5 \mathrm{~mm}$, which corresponds to the residual strength as labeled by a red square. The final crack opening 
on the bottom was measured as $0.43 \mathrm{~mm}$. After remediation, the sealed beam was bent again with a mechanical response curve in blue. The healing strength of the second-time bending corresponding to the peak noted by the red cycle was found to be much greater than residual strength. Such strength regaining might be attributed to the self-healing effect, i.e., the precipitation filling the crack gap to paste the fractured matrix.

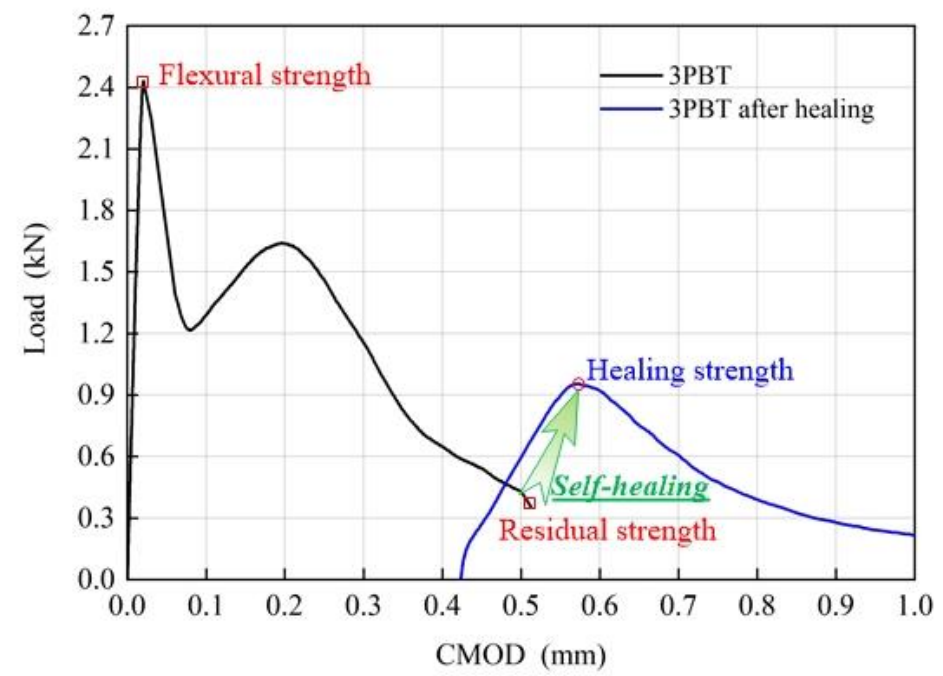

Figure 8. Bending responses of self-healing mortar.

\subsection{Characterization of Precipitation}

The post-damage beam specimens were broken into halves for further identification of the cracking surfaces. Afterwards, some white precipitations were carefully scraped and collected for a sequent SEM test. Some bacterial imprints were found in the crystals as depicted in Figure 9a, providing clues for the biomineralization occurring during crack sealing. In Figure 9b, it is implied that vaterite is the main morphology of calcium carbonate precipitations. This finding is in accordance with precipitation obtained from ureolytic MICP and crack-sealing precipitation of self-healing mortar in $[28,42,43]$. It is believed that vaterite precipitations filling the crack gap helped to rebuild the cohesion between the fractured surfaces.

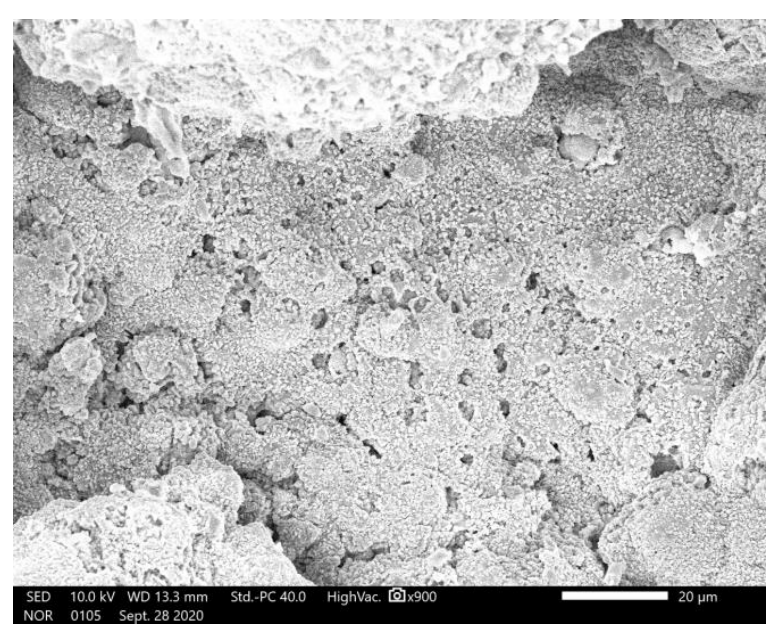

(a)

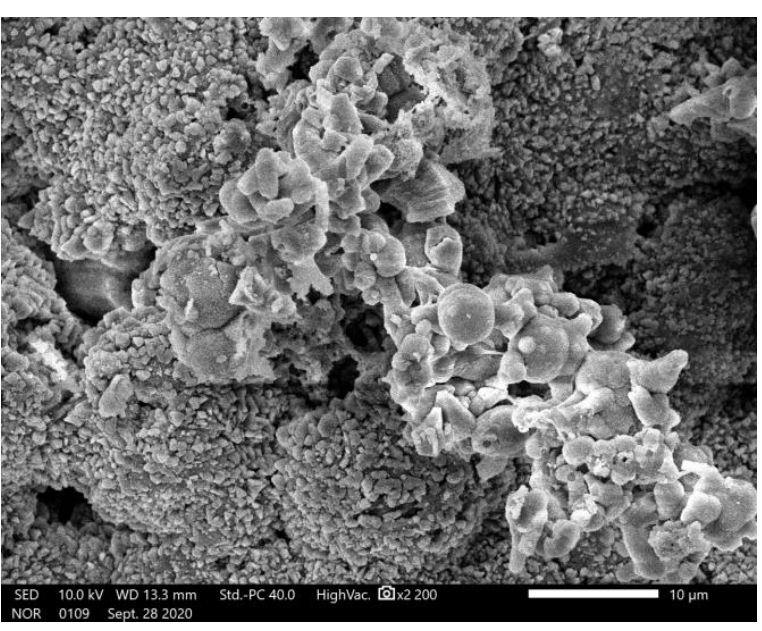

(b)

Figure 9. SEM image of recovered crack filler: (a) Calcium carbonate precipitation with cell imprints; (b) vaterite morphology.

Moreover, the PVA fibers after pullout from the matrix were also tested via SEM. Zooming in different scalings, Figure 10 shows fiber surface details, i.e., damage mode 
of the fiber and the adhering attachments. Clear circumferential fracture together with scratches on the rough surface result from debonding and sliding friction between fiber and surrounding matrix $[44,45]$. It is interesting to find a few tiny vaterite $\mathrm{CaCO}_{3}$ crystals adhering to the fiber surface. This phenomenon could be accounted for by the bond repair hypothesis that microcracks around the fiber-matrix interface are also healed thanks to ureolytic MICP during incubation.

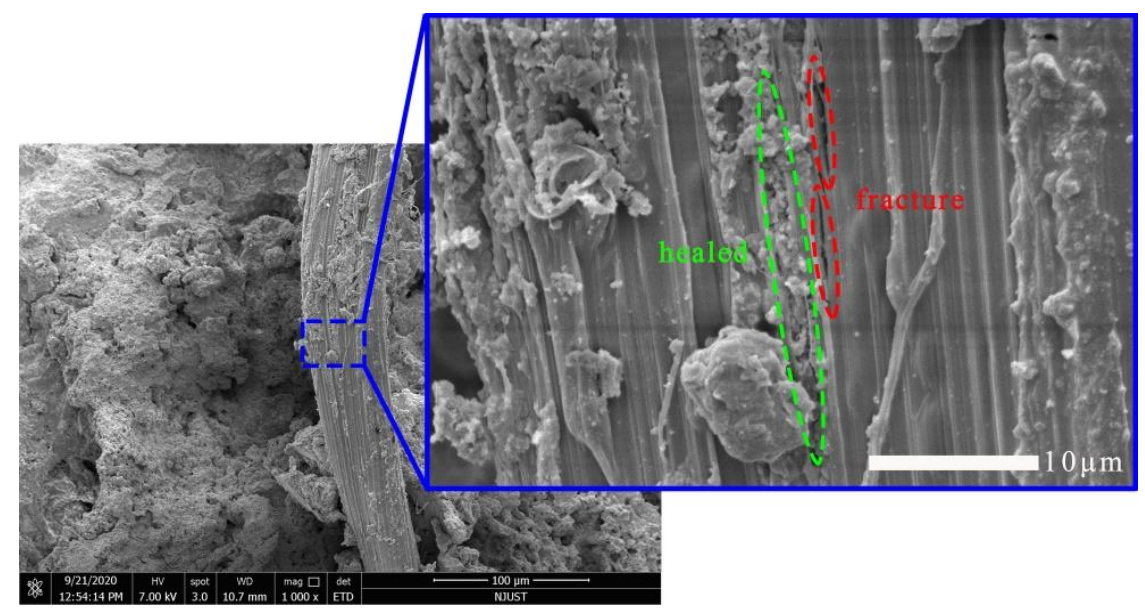

Figure 10. SEM image of PVA fiber after remediation.

\section{Conclusions}

The main purpose of this study was to explore ureolytic MICP with application to selfhealing mortar development. The artificial seawater incubation process was investigated with a crack-sealing evaluation. Several conclusions are drawn as follows: (1) $\mathrm{CaCO}_{3}$ of ureolytic MICP with Bacillus in this study is mainly vaterite with some calcite. (2) The produced self-healing mortar has a flexural strength of $9.02 \mathrm{MPa}$. (3) With artificial seawater incubation, the $0.4 \mathrm{~mm}$ width crack is autonomously healed more rapidly, at least for this experimental setting. For 7-day-old cracked samples, it took a week to seal the crack while 14-day-old remediation required 2 weeks. The shorter incubation time in a seawater environment might inspire researchers to develop self-healing mortar with a rapid cracksealing performance. (4) The healing-induced flexural strength regaining ranges from $0.12 \mathrm{MPa}$ to $1.67 \mathrm{MPa}$ for young self-healing mortar. However, the 28-day-old samples failed to heal completely. (5) With bacterial imprints, vaterite is the main morphology of $\mathrm{CaCO}_{3}$ filling the cracking gap. Calcium carbonate precipitation crystals adhere to the PVA fiber surface, suggesting a fiber-matrix bond repair.

Author Contributions: Conceptualization, Y.W. and J.F.; methodology, X.S.; investigation, S.C., J.C. and M.L.; data curation, J.C. and S.L.; writing—original draft preparation, X.S.; writing-review and editing, Y.W. and J.F.; visualization, S.L. and Y.N.; supervision, Y.W.; funding acquisition, J.F. All authors have read and agreed to the published version of the manuscript.

Funding: This research was funded by National Natural Science Foundation of China, grant number 11902161. The APC was funded by Natural Science Foundation of Jiangsu Province (No. BK20170824).

Institutional Review Board Statement: Not applicable.

Informed Consent Statement: Not applicable.

Data Availability Statement: The data presented in this study are available on request from the corresponding author. 
Acknowledgments: Jun Feng thanks the financial support provided by the Major Science and Technology Projects in Shanxi (No. 20201102003) and the Open Cooperative Innovation Fund of Xi'an Institute of Modern Chemistry (No. SYJJ200321). The AFM, XRD and SEM experiments were conducted at the Materials Characterization Facility of Nanjing University of Science \& Technology. Yuqi Wang, Zhigang Gao and Bingcheng Chen are acknowledged for their timely helps in conducting experiments.

Conflicts of Interest: The authors declare no conflict of interest.

\section{References}

1. Shah, K.W.; Huseien, G.F. Biomimetic Self-Healing Cementitious Construction Materials for Smart Buildings. Biomimetics 2020, 5, 47. [CrossRef]

2. Feng, J.; Song, M.; Sun, W.; Wang, L.; Li, W.; Li, W. Thick plain concrete targets subjected to high speed penetration of 30CrMnSiNi2A steel projectiles: Tests and analyses. Int. J. Impact Eng. 2018, 122, 305-317. [CrossRef]

3. Palin, D.; Wiktor, V.; Jonkers, H.M. A Bacteria-Based Self-Healing Cementitious Composite for Application in Low-Temperature Marine Environments. Biomimetics 2017, 2, 13. [CrossRef]

4. Li, W.; Dong, B.; Yang, Z.; Xu, J.; Chen, Q.; Li, H.; Xing, F.; Jiang, Z. Recent advances in intrinsic self-healing cementitious materials. Adv. Mater. 2018, 30, 1705679. [CrossRef]

5. Di Luzio, G.; Ferrara, L.; Krelani, V. Numerical modeling of mechanical regain due to self-healing in cement based composites. Cem. Concr. Compos. 2018, 86, 190-205. [CrossRef]

6. Abousnina, R.; Manalo, A.; Ferdous, W.; Lokuge, W.; Benabed, B.; Al-Jabri, K.S. Characteristics, strength development and microstructure of cement mortar containing oil-contaminated sand. Constr. Build. Mater. 2020, 252, 119155. [CrossRef]

7. Siddika, A.; Mamun, M.A.A.; Ferdous, W.; Saha, A.K.; Alyousef, R. 3D-printed concrete: Applications, performance, and challenges. J. Sustain. Cem. Based Mater. 2020, 9, 127-164. [CrossRef]

8. Van Tittelboom, K.; De Belie, N. Self-Healing in Cementitious Materials-A Review. Materials 2013, 6, 2182-2217. [CrossRef] [PubMed]

9. Feng, J.; Sun, W.; Zhai, H.; Wang, L.; Dong, H.; Wu, Q. Experimental Study on Hybrid Effect Evaluation of Fiber Reinforced Concrete Subjected to Drop Weight Impacts. Materials 2018, 11, 2563. [CrossRef] [PubMed]

10. Zhang, W.; Zhang, N.; Zhou, Y. Effect of flexural impact on freeze-thaw and deicing salt resistance of steel fiber reinforced concrete. Mater. Struct. 2016, 49, 5161-5168. [CrossRef]

11. Mignon, A.; Graulus, G.J.; Snoeck, D.; Martins, J.; De Belie, N.; Dubruel, P.; Van Vlierberghe, S. pH-sensitive superabsorbent polymers: A potential candidate material for self-healing concrete. J. Mater. Sci. 2015, 50, 970-979. [CrossRef]

12. Zhu, B.; Li, Q.; Chen, W.; Zou, W.; Chen, W. A Novel Method of Self-Healing in Cementitious Materials by Using Polyacrylic Hydrogel. KSCE J. Civ. Eng. 2020, 24, 3406-3415. [CrossRef]

13. Wang, J.Y.; Snoeck, D.; Van Vlierberghe, S.; Verstraete, W.; De Belie, N. Application of hydrogel encapsulated carbonate precipitating bacteria for approaching a realistic self-healing in concrete. Constr. Build. Mater. 2014, 68, 110-119. [CrossRef]

14. Wiktor, V.; Jonkers, H.M. Quantification of crack-healing in novel bacteria-based self-healing concrete. Cem. Concr. Compos. 2011, 33, 763-770. [CrossRef]

15. Jonkers, H.M.; Thijssen, A.; Muyzer, G.; Copuroglu, O.; Schlangen, E. Application of bacteria as self-healing agent for the development of sustainable concrete. Ecol. Eng. 2010, 36, 230-235. [CrossRef]

16. Vermeer, C.M.; Rossi, E.; Tamis, J.; Jonkers, H.M.; Kleerebezem, R. From waste to self-healing concrete: A proof-of-concept of a new application for polyhydroxyalkanoate. Resour. Conserv. Recycl. 2021, 164, 105206. [CrossRef]

17. Van Tittelboom, K.; Wang, J.; Araújo, M.; Snoeck, D.; Gruyaert, E.; Debbaut, B.; Derluyn, H.; Cnudde, V.; Tsangouri, E.; Van Hemelrijck, D.; et al. Comparison of different approaches for self-healing concrete in a large-scale lab test. Constr. Build. Mater. 2016, 107, 125-137. [CrossRef]

18. Gollapudi, U.K.; Knutson, C.L.; Bang, S.S.; Islam, M.R. A new method for controlling leaching through permeable channels. Chemosphere 1995, 30, 695-705. [CrossRef]

19. Bang, S.S.; Galinat, J.K.; Ramakrishnan, V. Calcite precipitation induced by polyurethane-immobilized Bacillus pasteurii. Enzym. Microb. Technol. 2001, 28, 404-409. [CrossRef]

20. Xu, J.; Wang, X. Self-healing of concrete cracks by use of bacteria-containing low alkali cementitious material. Constr. Build. Mater. 2018, 167, 1-14. [CrossRef]

21. Feng, J.; Chen, B.; Sun, W.; Wang, Y. Microbial induced calcium carbonate precipitation study using Bacillus subtilis with application to self-healing concrete preparation and characterization. Constr. Build. Mater. 2021, 280, 122460. [CrossRef]

22. Su, Y.; Feng, J.; Zhan, Q.; Zhang, Y.; Qian, C. Non-ureolytic microbial self-repairing concrete for low temperature environment. Smart Mater. Struct. 2019, 28, 075041. [CrossRef]

23. Qian, C.; Chen, H.; Ren, L.; Luo, M. Self-healing of early age cracks in cement-based materials by mineralization of carbonic anhydrase microorganism. Front. Microbiol. 2015, 6, 1225. [CrossRef] [PubMed]

24. Vijay, K.; Murmu, M.; Deo, S.V. Bacteria based self healing concrete-A review. Constr. Build. Mater. 2017, 152, 1008-1014. [CrossRef] 
25. Zhu, T.; Dittrich, M. Carbonate precipitation through microbial activities in natural environment, and their potential in biotechnology: A review. Front. Bioeng. Biotechnol. 2016, 4, 588-590. [CrossRef] [PubMed]

26. Durga, C.S.S.; Ruben, N.; Chand, M.S.R.; Venkatesh, C. Performance studies on rate of self healing in bio concrete. Mater. Today Proc. 2020, 27, 158-162. [CrossRef]

27. Zhang, W.; Ju, Y.; Zong, Y.; Qi, H.; Zhao, K. In Situ Real-Time Study on Dynamics of Microbially Induced Calcium Carbonate Precipitation at a Single-Cell Level. Environ. Sci. Technol. 2018, 52, 9266-9276. [CrossRef] [PubMed]

28. $\mathrm{Xu}, \mathrm{J}$; W Wang, $\mathrm{X}$.; Wang, B. Biochemical process of ureolysis-based microbial $\mathrm{CaCO}_{3}$ precipitation and its application in self-healing concrete. Appl. Microbiol. Biotechnol. 2018, 102, 3121-3132. [CrossRef] [PubMed]

29. Lee, Y.S.; Park, W. Current challenges and future directions for bacterial self-healing concrete. Appl. Microbiol. Biotechnol. 2018, 102, 3059-3070. [CrossRef] [PubMed]

30. Zheng, T.; Su, Y.; Qian, C.; Zhou, H. Low alkali sulpho-aluminate cement encapsulated microbial spores for self-healing cement-based materials. Biochem. Eng. J. 2020, 163, 107756. [CrossRef]

31. Suleiman, A.R.; Nehdi, M.L. Effect of environmental exposure on autogenous self-healing of cracked cement-based materials Cem. Concr. Res. 2018, 111, 197-208. [CrossRef]

32. Liu, H.; Huang, H.; Wu, X.; Peng, H.; Li, Z.; Hu, J.; Yu, Q. Effects of external multi-ions and wet-dry cycles in a marine environment on autogenous self-healing of cracks in cement paste. Cem. Concr. Res. 2019, 120, 198-206. [CrossRef]

33. Hamza, O.; Esaker, M.; Elliott, D.; Souid, A. The effect of soil incubation on bio self-healing of cementitious mortar. Mater. Today Commun. 2020, 24, 100988. [CrossRef]

34. Wang, J.; Jonkers, H.M.; Boon, N.; De Belie, N. Bacillus sphaericus LMG 22257 is physiologically suitable for self-healing concrete. Appl. Microbiol. Biotechnol. 2017, 101, 5101-5114. [CrossRef]

35. Su, Y.; Qian, C.; Rui, Y.; Feng, J. Exploring the coupled mechanism of fibers and bacteria on self-healing concrete from bacterial extracellular polymeric substances (EPS). Cem. Concr. Compos. 2021, 116, 103896. [CrossRef]

36. Kalhori, H.; Bagherpour, R. Application of carbonate precipitating bacteria for improving properties and repairing cracks of shotcrete. Constr. Build. Mater. 2017, 148, 249-260. [CrossRef]

37. Huang, H.; Ye, G. Self-healing of cracks in cement paste affected by additional $\mathrm{Ca}^{2+}$ ions in the healing agent. J. Intell. Mater. Syst. Struct. 2015, 26, 309-320. [CrossRef]

38. Cusatis, G.; Jin, C.; Du, M.; Feng, J.; Zhou, X. Experimental and Numerical Characterization of Pullout Behavior of Hooked Steel Fibers in Ultra-High Performance Cementitious Matrix. In Proceedings of the International Interactive Symposium on Ultra-High Performance Concrete, Ames, IA, USA, 18 July 2016; Volume 1.

39. Yao, W.; Sun, W.; Shi, Z.; Chen, B.; Chen, L.; Feng, J. Blast-Resistant Performance of Hybrid Fiber-Reinforced Concrete (HFRC) Panels Subjected to Contact Detonation. Appl. Sci. 2020, 10, 241. [CrossRef]

40. Feng, J.; Gao, X.; Li, J.; Dong, H.; Yao, W.; Wang, X.; Sun, W. Influence of fiber mixture on impact response of ultra-highperformance hybrid fiber reinforced cementitious composite. Compos. Part B Eng. 2019, 163, 487-496. [CrossRef]

41. Menon, R.R.; Luo, J.; Chen, X.; Zhou, H.; Liu, Z.; Zhou, G.; Zhang, N.; Jin, C. Screening of fungi for potential application of self-healing concrete. Sci. Rep. 2019, 9, 2075. [CrossRef] [PubMed]

42. Chahal, N.; Siddique, R. Permeation properties of concrete made with fly ash and silica fume: Influence of ureolytic bacteria. Constr. Build. Mater. 2013, 49, 161-174. [CrossRef]

43. Wang, J.; Ersan, Y.C.; Boon, N.; De Belie, N. Application of microorganisms in concrete: A promising sustainable strategy to improve concrete durability. Appl. Microbiol. Biotechnol. 2016, 100, 2993-3007. [CrossRef] [PubMed]

44. Zheng, X.; Easa, S.M.; Yang, Z.; Ji, T.; Jiang, Z. Life-cycle sustainability assessment of pavement maintenance alternatives: Methodology and case study. J. Clean. Prod. 2019, 213, 659-672. [CrossRef]

45. Zhang, W.; Chen, S.; Liu, Y. Effect of weight and drop height of hammer on the flexural impact performance of fiber-reinforced concrete. Constr. Build. Mater. 2017, 140, 31-35. [CrossRef] 